pressed-the desire for salaries which has been so conspicuous whenever professors have descanted on the merits of research. We have not the slightest objection to scientific departments, and quite agree with Sir Lyon Playfair that if the State wants fishes it could learn how to get them better by inquiring of the fishes-who, at least, tell no lies-than of the fishermen, who often do; but still the picture he draws of the United States Government, with its dozen departments of inquiry into geology, palæontology, ichthyology, chemistry, and the rest, does not inspire us with enthusiasm. It is all very excellent, no doubt ; but it was all consistent with slavery. France may be handed over to Paul Berts and its judges still take bribes."

The Glasgow Herald pronounces Sir Lyon Playfair's address a signal success. Those pedantic persons who fail to see the uses of science might find in the address an admirable lesson against the perpetual snecring at what they are pleased to term the abstractions of scientific teaching. Sir Lyon, in a word, has emphasised the teaching that the safety and the progress of every country are one with scientific advance and the growth of scientific precision.

On the whole, then, it may be pronounced that the movement in favour of State aid to science, in the interest of the State itself rather than of any particular branch of human knowledge, has advanced and has taken a hold of the public mind. The need is universally acknowledged ; in many quarters it is proposed to meet it by the application of endowments, ancient and modern, to the changed requirements of the present day; in others-and these amongst the influential-it is boldly declared that the State must link itself, at whatever cost, with science if this country is to hold its high place amongst nations "The same considerations by which State interference has been justified elsewhere-its greater certainty, its ampler resources, its wider range-are all equally applicable here, and will come to be equally applied."

\section{LETTERS TO THE EDITOR}

[ The Editor does not hold himself responsible for opinions expressed by his correspondents. Neither can he undertake to return, or to correspond with the writers of, rejected manuscripts. No notice is taken of anonymous communications.

[The Editor urgently requests correspondents to keep their letters as short as possible. The pressure on his space is so great that it is impossible otherzvise to insure the appearance even of communications containing interesting and novel facts.]

\section{The New Star in Andromeda}

ON seeing the report in yesterday's Standard of the remarkable change in the nucleus of the nebula of Andromeda, I decided to write to you to mention that, accidentally noticing the nebula on Sunday evening, the $6 \mathrm{th}$, I was struck by its conspicuousness, and set wondering how the ancients came to overlook an object so prominent. As frequent watching for meteors has made that region very familiar to me, it seems likely that an increase in general brightness has occurred, and made me specially notice its appearance.

What is of far more interest, however, I have learnt this morning that one of our scholars, Lawrence Richardson, noted and recorded an apparent change in the nebula, as he saw it in our $4^{\frac{1}{4}}$ inch Cooke's refractor, about 9 p.m. September I. I append a verbation copy from his diary of what is perhaps the first English observation of this remarkable phenomenon.

Friends' School, Bootham, York, September 9

J. EDMUND CLARK

(Copy) "Sept. I . . . As a beginning [of the scason's work] looked at Polaris, $\epsilon$ Lyræ and the great nebula of Andromeda. Noticed a small star in the centre of the latter which I do not

remember having seen before, and which is not down in a small drawing I made on September I 5, 1884 .

\title{
Norwegian Testimony to the Aurora-Sound
}

How widespread in our days is the belief in the sound of the Aurora in Norway, the following may show. In March, 1885, I despatched some thousand circulars to all parts of the country containing different queries regarding the aurora, and amongst these also the following :- Have you or your acquaintan'ces ever heard any sound during aurora, and, in this case, when and in what manner? $U_{p}$ to this date I have received answers to these queries from I44 persons in different parts of the country. Of these there are not less than 92 , or 64 per cent., who believe in the existence of the aucora-sound, and 53 (36 per cent.) of these again state they have heard it themselves, whilst the other 39 cite testimonials from other people ; only $\mathbf{2 I}$ (I 5 per cent.) declare they never hav heard the sound or know anything about it, and the other 3I $(22$ per cent.) have not noticed the query at all. There are thus 92 affirmations against 21 negations.

The sound is describet in these answers in the following manner:-

Sizzling (3)

Creaking or sizzling

An intermediate sound between sizzling and whizzing, sometimes as if a piece of paper were torn

A kind of sound as when you tear silk

Sizzling, th-ss

Soft whizzing, alternative with sizzling

Soft crackling, sizzling

Hissing and crackling

Partly hissing, partly as a kind of rushing whiz

Whispering and glistering

Strong whiz (3)

Whiz or whispering

Whiz, or distant, soft, continuous whizzing

A rather heavy rush, as from a distant waterfall

Quiet whizzing, hissing

Hissing, or hoy ! hoy ! hoy!

Whiz (2)

Rush, as from a stream

Soft but distant crackling, as

from a lighted match-cord

Whizzing (5)

Whizzing in the air

Rush, as when sheep are chased

Soft whiz or hissing

Soft whiz

Soft hissing, soft whiz

Whizzing or whistling

Rippling

Crackling (4)

Hissing

Hissing noise in the air

Crack in the air

Din in the air

Continuous sounding, rolling din in the air

Clashing

Flapping, as a flag before the wind

Partly as rustling or flapping of sails hanging loose fore the wind, partly as hissing from fire

Like the noise from a distant, before the wind-flapping flag, which now and then sends out a creaking sound

Like the sound from sails of a ship hanging loose in stormy weather
Monotonous whizzing and creaking, as when a sheet flaps before the wind

Like burning juniper-boughs

Brustling or crackling as if burning juniper

As from a feeble burning flame

Like burning dried juniper

As from the flames of a conflagration

Cutting, hissing as from flame:

Crackling and creaking, a noise as from a large fire-flameas, for instance, burning dried boughs

Like the sound from a flight of birds

Noise as when a bird flaps in the air

Strong flapping noise, as when a bird passes very near you

Crackling from fire and flapping from wings

As of a bird flying through the air with great velocity

Whizzing noise, as when striking the air with a whip

Noise as from the dart of an arrow

Like the buzzing of a bee

Roaring noise, as when strong gushes of wind dart through the tree-tops of the wood

Creaking sound as from the blowing of the wind

Distant roar, as from a storm

Roaring as from a storm

Roaring as from a whirlwind

As from a soft-blowing wind

Soft breeze

Like the soft breeze through a wood

Whipping with whisk-brooms

Fanning

Soft noise, as when fanning with a piece of paper from a distance

Soft flapping with a piece of cloth

Roaring of the sea

Heavy, hollow roar from the sea

Sweeping sound, as when dry snow is sweeping over an ice-field

As when one holds a cloth by two corners and flaps with it 